\section{Received}

May, $29^{\text {th }} 2021$
Accepted

Jun, $26^{\text {th }} 2021$
Published

Jun, $27^{\text {th }} 2021$

\title{
Personality Competencies of Counselor School and Their Impact on Students' Personalities
}

\author{
Rismar Julia Utami \\ STKIP Muhammadiyah Sungai Penuh , Jambi, Indonesia. \\ *)E-mail: rismarjuliautami7@gmail.com
}

\begin{abstract}
The existence of Guidance and Counseling Teachers as one of the educators has the task of developing the potential and independence of students. Therefore, the competence of the BK teacher is needed in shaping the student's personality to become a superior person which is applied in the school environment. The purpose of this study was to determine the personality competencies of BK teachers and their impact on students' personalities. This research was conducted at SMP Negeri 1 Kerinci. The population in this study were 399 students, the sampling technique used proportional random sampling with a sample of 120 people. Furthermore, to determine the extent of the teacher's personality competence, a sample of 3 BK teachers was taken. Methods of collecting data using a questionnaire, a questionnaire about the personality competencies of teachers and students. Data analysis used descriptive percentage analysis. Based on data analysis, it was found that the highest aspect of teacher competence is faith and piety to God Almighty, while the highest aspect of student personality is displaying noble character.
\end{abstract}

Keywords: Personality Competence; Teacher; Guidance and Counseling, Student Personality.

\begin{abstract}
Abstrak
Keberadaan Guru Bimbingan dan Konseling sebagai salah satu tenaga pendidik mempunyai tugas mengembangkan potensi dan memandirikan siswa. Oleh karena itu, diperlukanlah kompetensi dari guru BK dalam membentuk pribadi siswa menjadi pribadi yang unggul yang diterapkan di dalam lingkungan sekolah tersebut. Tujuan dari penelitian ini adalah untuk mengetahui kompetensi kepribadian guru BK dan dampaknya terhadap kepribadian siswa. Penelitian ini dilakukan di SMP Negeri 1 Kerinci. Populasi dalam penelitian ini sebanyak 399 siswa, teknik pengambilan sampel menggunakan teknik propotional random sampling dengan sampel sebanyak 120 orang. Selanjutnya untuk mengetahui sejauhmana kompetensi kepribadian guru diambil sampel guru BK sebanyak 3 orang. Metode pengumpulan data menggunakan angket, angket tentang kompetensi kepribadian guru dan siswa. Analisis data menggunakan analisis deskriptif persentase. Berdasarkan analisis data diperoleh hasil bahwa aspek tertinggi pada kompetensi guru yaitu beriman dan bertakwa kepada Tuhan Yang Maha Esa, sedangkan pada kepribadian siswa aspek tertinggi yaitu menampilkan akhlak mulia.
\end{abstract}

Kata Kunci: Kompetensi Kepribadian; Guru; Bimbingan dan Konseling, Kepribadian Siswa 


\section{PENDAHULUAN}

Sekolah menengah pertama (SMP) merupakan salah satu jenjang pendidikan yang memiliki peranan penting dalam mengembangkan berbagai aspek kehidupan yang meliputi perkembangan pendidikan pribadi, sosial, belajar, dan karir. Namun dalam kenyataan di lapangan menunjukan bahwa untuk mencapai tujuan tersebut tidaklah mudah, dalam kaitan ini bimbingan konseling mempunyai peranan yang sangat penting di sekolah; yaitu membantu setiap pribadi peserta didik agar berkembang secara optimal. Untuk menghasilkan output yang berakhlak baik dan berkepribadian tentunya perlu pembinaan yang berkesinambungan.

Keberadaan bimbingan dan konseling di sekolah bertujuan untuk membantu siswa mengembangkan dirinya dan menyelesaikan masalahnya sehingga tahap perkembangannya tidak terganggu. Untuk mencapai tujuan ini, maka perlu dilaksanakan layanan bimbingan dan konseling yang bermutu. Perwujudan dari layanan bimbingan dan konseling yang bermutu di sekolah tidak lepas dari peran guru bimbingan dan konseling (selanjutnya disingkat BK). Keberhasilan layanan bimbingan dan konseling sangat dipengaruhi oleh kinerja guru BK dalam melaksanakan tugasnya.

Guru BK di sekolah memiliki peran dan tugas yang berbeda dengan guru mata pelajaran. Selain memiliki tugas untuk membimbing semua siswa asuhnya, guru BK memiliki tugas untuk memberikan layanan konseling kepada siswa yang memerlukan Tugas utama guru BK adalah membantu siswa untuk menyelesaikan masalah-masalah pribadi siswa yang berhubungan dengan pendidikan dan pelajaran.

Beragamnya tugas yang ditanggungnya, guru BK harus menguasai berbagai kompetensi untuk menunjang kinerjanya. Profesi guru BK yang termasuk dalam profesi pendidikan, sudah pasti memiliki standar kualifikasi dan kompetensi sebagaimana tercantum dalam Peraturan Menteri Pendidikan Nasional Nomor 27 Tahun 2008 ada beberapa kompetensi yang harus dimiliki oleh konselor, diantaranya; kompetensi pedagogik, kompetensi sosial, kompetensi professional, kompetensi kepribadian (Badan Nasional Sertifikasi Profesi, 2008).

Kompetensi kepribadian adalah salah satu kompetensi yang harus dimiliki oleh seorang guru yang berkaitan dengan tingkah laku pribadi guru itu sendiri yang kelak harus memiliki nilai-nilai luhur sehingga terlihat dalam perilaku sehari-hari. Pada kompetensi kepribadian guru BK perlu memiliki kepribadian yang meliputi beriman dan bertaqwa kepada Tuhan Yang Maha Esa, menghargai dan menjunjung tinggi nilai-nilai kemanusiaan, individualitas dan kebebasan memilih, menunjukkan integritas dan stabilitas kepribadian yang kuat serta menampilkan kinerja berkualitas yang tinggi (Saudagar \& Idrus, 2011). 
Selanjutnya, kompetensi kepribadian guru merupakan kemampuan yang dimiliki oleh guru yang bersifat rasional dalam melaksanakan tugas yang di emban (Wardati, 2018). Berdasarkan hal ini guru BK juga dituntut harus memahami secara mendalam konseli yang dilayani, menguasai landasan dan kerangka teoritik bimbingan dan konseling, menyelenggarakan pelayanan bimbingan dan konseling yang memandirikan konseli, mengembangkan pribadi dan profesionalitas konselor secara berkelanjutan.

Sebagaimana yang telah disebutkan bahwa salah satu kompetensi yang harus dimiliki guru BK adalah kompetensi kepribadian. Pasalnya untuk mewujudkan pelayanan yang optimal dan bermutu, layanan bimbingan dan konseling harus diberikan oleh guru BK yang profesional dan memiliki kepribadian menyenangkan. Guru BK yang mempunyai profil kompetensi kepribadian yang baik harus menjadi suri tauladan bagi siswa, maka guru BK harus menampilkan pribadi yang baik, bukan hanya baik dari luar tetapi baik pula dari dalam. Kepribadian bukanlah hal yang dapat dinilai dari luar tetapi merupakan sebuah hasil pencitraan dari dalam diri masing-masing individu. Semakin baik kepribadian guru BK dalam menangani masalah siswa maka akan baik pula pandangan atau persepsi siswa terhadap konselornya. Oleh karena itu, kompetensi kepribadian seorang guru BK merupakan faktor yang sangat penting dan berpengaruh terhadap kebermutuan layanan bimbingan dan konseling di sekolah.

SMP Negeri 1 dengan akreditasi yang baik merupakan sekolah favorit di Kabupaten Kerinci, dengan adanya image tersebut maka semua stekholder yang ada di dalamnya menjadi fokus utama dalam membangun dan membentuk citra yang baik di mata siswa/siswi dan masyarakat disekitarnya. Namun masih ditemukan masalah mengenai pelaksanaan layanan bimbingan konseling yang belum maksimal karena siswa/siswi secara keseluruhan masih kurang positif dalam pelayanan bimbingan konseling yang ada di sekolah.

Berdasarkan hasil studi lapangan di SMP Negeri 1 Kerinci terlihat bahwa siswa kurang meminati pelayanan bimbingan dan konseling. Hal ini dilihat dari gejala siswa yangseperti takut, malas, dan enggan untuk mengikuti dan berperan aktif pada layanan-layanan bimbingan dan konseling. Siswa juga menganggap bahwa bimbingan dan konseling adalah suatu bagian yang khusus menangani masalah siswa yang melanggar peraturan sekolah, seperti terlambat, membolos, berkelahi, merokok, dan sebagainya. Sehingga siswa enggan untuk berurusan dengan guru BK karena takut dianggap siswa yang bermasalah. Faktor lain yang menyebabkan hal tersebut adalah siswa memiliki persepsi bahwa guru BK itu kepribadian yang kurang ramah terhadap siswa dalam mengatasi permasalahan. Kemudian sebagian siswa juga mengungkapkan bahwa hubungannya dengan 
guru BK masih belum akrab dan merasa canggung untuk meminta konseling dengan guru BK.

Keberadaan guru BK hendaknya sebagai salah satu tenaga pendidik, sejajar dengan guru, dosen, pamong belajar, tutor, widyaiswara, fasilitator, dan instruktur. Tugas guru BK berada dalam kawasan pelayanan yang bertujuan mengembangkan potensi dan memandirikan individu dalam pengambilan keputusan dan pilihan untuk mewujudkan kehidupan yang produktif, sejahtera, dan peduli kemaslahatan umum. Oleh karena itu, diperlukanlah peran dari guru BK dalam membentuk pribadi siswa menjadi pribadi yang unggul yang diterapkan di dalam lingkungan sekolah tersebut.

Bimbingan dan konseling adalah upaya sistematis, objektif, logis, dan berkelanjutan serta terprogram yang dilakukan oleh konselor atau guru Bimbingan dan Konseling untuk memfasilitasi perkembangan peserta didik/konseli untuk mencapai kemandirian dalam kehidupannya. Guru BK bertanggung jawab untuk membimbing siswa sehingga para siswa dapat memiliki pribadi yang unggul tersebut. Dengan demikian diharapkan para siswa mampu untuk membuat keputusan yang terbaik untuk dirinya, baik dalam memecahkan masalah mereka sendiri maupun dalam beradaptasi dengan keadaan lingkungan masyarakat tempat ia tinggal.

Penelitian terkait dengan kompetensi kepribadian guru pada dasarnya sudah banyak dilakukan oleh peneliti lainnya, seperti kompentensi kepribadian guru Pendidikan Agama Islam (Alimin, 2015; Prasetiya, 2013), kompetensi kepribadian guru PPKn (Susanti et al., 2017), dan kompetensi guru IPA (Rahmiyanda et al., 2016). Namun, belum ditemukan penelitian tentang kompentensi kepribadian guru BK. Maka dari itu, peneliti menganggap hal ini penting untuk ditelusuri lebih lanjut.

\section{METODE PENELITIAN}

Penelitian ini tergolong kepada penelitian deskriptif yaitu untuk menggambarkan fenomena yang ada dengan tepat dan akurat. Penelitian ini bertujuan untuk mendeskripsikan dan mengungkapkan data apa adanya yaitu mengenai kompetensi kepribadian guru bimbingan dan konseling dan dampaknya terhadap kepribadian siswa di SMP Negeri 1 Kerinci. Populasi dalam penelitian ini sebanyak 399 siswa. Sampel penelitian diambil menggunakan teknik propotional random sampling sebanyak 120 orang. Selanjutnya untuk mengetahui sejauhmana kompetensi kepribadian guru diambil sampel guru BK sebanyak 3 orang.

Kompetensi kepribadian yang dimaksud dalam penelitian ini adalah kepribadian yang harus melekat pada konselor yang merupakan: 1) Beriman dan 
bertaqwa kepada Tuhan YME, 2) Menghargai dan menjunjung tinggi nilai-nilai kemanusiaan, individualitas dan kebebasan untuk memilih, 3) Menunjukkan integritas dan stabilitas kepribadian yang kuat, 4) Menampilkan kinerja berkualitas tinggi. Sedangkan Kepribadian siswa yang dinyatakan sebagai pribadi yang unggul terlihat dari beberapa aspek diantaranya: 1) Akhlak mulia, 2) Displin dalam menggunakan waktu, 3) Mandiri, 4) Percaya diri.

Data penelitian dikumpulkan menggunakan Angket yang telah diuji validitas dan reliabilitasnya. Pengolahan data dalam penelitian ini dilakukan dengan cara menghitung persentase jawaban responden dengan menggunakan rumus (Yusuf, 2013).

\section{HASIL PENELITIAN DAN PEMBAHASAN}

Penelitian ini bertujuan untuk mengungkap gambaran salah satu aspek dari empat kompetensi Guru BK yaitu kompetensi kepribadian, kompetensi ini merupakan kemampuan seorang koselor atau guru BK untuk menjadi pribadi yang memiliki integritas dan menunjukkan kinerja yang berkualitas dalam kehidupannya sehari-hari.

\section{Deskripsi Kompetensi Kepribadian Guru BK}

Berdasarkan angket yang telah disebarkan kepada 3 guru BK yang seluruhnya berlatar belakang pendidikan bimbingan dan konseling, berikut hasil analisis data terkait pemahaman guru BK tentang Kompetensi Kepribadian yang diperoleh dari penelitian yang peneliti lakukan:

Tabel 1. Hasil Persentase Pemahaman Guru BK Tentang Kompetensi Kepribadian

\begin{tabular}{|c|c|c|c|}
\hline Sub variabel & $\mathbf{F}$ & $\%$ & Kriteria \\
\hline Beriman dan bertakwa kepada Tuhan Yang Maha Esa & 92 & 76,4 & Baik \\
\hline $\begin{array}{l}\text { Menghargai dan menjunjung tinggi nilai- nilai } \\
\text { kemanusiaan dan kebebasan untuk memilih }\end{array}$ & 86 & 71,5 & Baik \\
\hline $\begin{array}{l}\text { Menunjukan integritas dan stabilitas kepribadian yang } \\
\text { kuat }\end{array}$ & 88 & 73,2 & Baik \\
\hline Menampilkan kinerja berkualitas tinggi & 87 & 72,5 & Baik \\
\hline
\end{tabular}

\section{Dampak Kompetensi Kepribadian Guru BK Terhadap Kepribadian Siswa}

Berdasarkan angket yang disebarkan kepada 120 siswa SMP Negeri 1 Kerinci dapat dilihat bahwa kompetensi kepribadian guru BK berdampak pada kepribadian siswa terlihat dalam empat indikator yang dapat dilihat dari persentase jawaban siswa dalam tabel berikut ini: 
Tabel 2. Hasil Persentase Dampak Kompetensi Kepribadian Guru BK Terhadap Kepribadian Siswa

\begin{tabular}{|c|c|c|c|c|}
\hline No & Sub variabel & $\mathbf{F}$ & $\%$ & Kriteria \\
\hline 1 & Akhlak mulia & 93 & 77 & Baik \\
\hline 2 & Disiplin & 85 & 70 & Cukup Baik \\
\hline 3 & Mandiri & 87 & 72 & Cukup Baik \\
\hline 4 & Percaya diri & 89 & 74 & Cukup Baik \\
\hline
\end{tabular}

Berdasarkan Undang-Undang Republik Indonesia nomor 14 Tahun 2005, tentang guru dan dosen bahwa kompetensi pendidik/ guru meliputi kompetensi pedagogik, kompetensi profesional, kompetensi sosial dan kompetensi kepribadian. Dari keempat kompetensi tersebut, ada satu kompetensi yang sangat besar pengaruhnya terhadap pertumbuhan dan perkembangan peserta didik yaitu kompetensi kepribadian. Kompetensi kepribadian ini memiliki peran dan fungsi yang sangat penting dalam membentuk kepribadian pesrta didik.

Berdasarkan hasil analisis deskriptif didapatkan bahwa pemahaman Guru BK tentang kompetensi kepribadian di SMP Negeri 1 Kerinci termasuk dalam kriteria baik. Hal ini menunjukkan bahwa secara keseluruhan Guru BK SMP N 1 Kerinci telah memahami dengan baik tentang kompetensi kepribadian dalam pelaksanaan pelayanan bimbingan dan konseling di sekolah.

Sesuai dengan Permendiknas tentang standar kualifikasi akademik dan kompetensi Guru BK No. 27 tahun 2008 yang menyebutkan bahwa kompetensi kepribadian terdiri dari empat variabel yaitu ; beriman dan bertaqwa kepada Tuhan Yang Maha Esa, menghargai dan menjunjung tinggi nilai - nilai kemanusiaan, individualitas dan kebebasan untuk memilih, menunjukkan integritas dan stabilitas kepribadian yang kuat, dan menampilkan kinerja berkualitas tinggi (Badan Nasional Sertifikasi Profesi, 2008).

Kegiatan layanan bimbingan dan konseling adalah kegiatan dimana Guru BK harus memahami siswa (konseli). Memahami siswa menuntut keterbukaan hati dan melepaskan cara befikir kaku dari seorang Guru BK. Untuk dapat berkomunikasi dengan siswa, Guru BK harus dapat menghargai dan memahami orang lain. Namun sebelum memahami siswa akan lebih baik apabila soerang Guru BK belajar memahami dirinya sendiri terlebih dahulu.

George dan Cristiani mengemukakan bahwa faktor personal Guru BK turut mempengaruhi efektifitas hubungan konseling (Latipun, 2006). Pernyataan di atas dapat memperkuat alasan bahwa kompetensi kepribadian Guru BK sangat berpengaruh pada saat proses berjalannya pemberian bantuan atau layanan kepada siswa. Kompetensi kepribadian merupakan salah satu faktor penting dalam menentukan profesionalitas sebuah pelayanan bimbingan dan konseling. 
Heru Mugiarso menyatakan "Pola 17" yang dijadikan menu dalam pelayanan bimbingan dan konseling. Dalam penyelenggaraannya, Guru BK perlu memahami makna dari tiap - tiap layanan agar tidak terjadi kesalahan dalam pelaksanaan pelayanan tersebut. Keberhasilan Guru BK dalam melaksanakan pelayanan bimbingan dan konseling tidak terlepas dari pemahaman Guru BK itu sendiri dari kualitas kepribadian dirinya yaitu 1.) mengenali diri sendiri, 2.) memahami orang lain, 3.) kemampuan berkomunikasi dengan orang lain (Winkel \& Hastuti, 2007).

Kaitan hal tersebut dengan penelitian ini tentunya adalah kualitas sebuah pelayanan bimbingan dan konseling yang diberikan oleh Guru BK salah satunya ditentukan kompetensi kepribadian yang dalam pelaksanaan akan berdampak terhadap kepribadian siswa. Seorang Guru BK yang telah memahami kompetensi kepribadian dengan baik, maka dalam memberikan pelayanan akan selalu memperhatikan empat aspek yaitu Beriman dan bertakwa kepada Tuhan Yang Maha Esa, Menghargai dan menjunjung tinggi nilai- nilai kemanusiaan dan kebebasan untuk memilih, Menunjukan integritas dan stabilitas kepribadian yang kuat, Menampilkan kinerja berkualitas tinggi.

Kompetensi kepribadian merupakan karakteristik pribadi efektif yang dimiliki oleh guru sebagai individu yang mantap, stabil, dewasa, bijaksana, berwibawa, menjadi teladan bagi peserta didik, dan berakhlak mulia. Kompetensi kepribadian ini dapat memberikan warna dalam pelaksanaan pembelajaran di sekolah dan menjadi figur identifikasi/tokoh teladan para siswanya sehingga "guru adalah orang yang harus digugu dan ditiru" tidak hanya sebatas semboyan masa lalu tetapi menyiratkan makna yang begitu mendalam.

Kepribadian guru akan terwujud melalui berfungsinya keseluruhan potensi manusiawi secara penuh dan utuh melalui interaksi antara diri dengan lingkungannya. Manusia lahir dengan membawa berbagai potensi sebagai anugerah (Surya, 2003). Poténsi manusiawi yang dimaksud menurut Hitt berbentuk daya nalar sebagai pilar penyangga dengan empat jenjang anak tangga, berupa: (1) coping, yaitu kemampuan untuk melakukan tindakan dalam menghadapi dunia sehari-hari dengan baik; (2) knowing, yaitu memahami kenyataan dan kebenaran dunia sehari-hari; (3) believing, yaitu keyakinan yang melandasi berbagai tindakan; dan (4) being, yaitu perwujudan din yang otentik dan bermakna (Surya, 2003). Meskipun guru BK bertanggung jawab penuh dalam pelaksanaan layanan bimbingan dan konseling di sekolah, guru BK juga memerlukan dukungan dan kerjasama dari pihak lain, dalam hal ini guru pembimbing bekerjasama dengan personil sekolah seperti guru kelas, guru mata pelajaran, wakil kepala sekolah bidang kesiswaan dan kepala sekolah untuk mendukung dan memaksimalkan kegiatan bimbingan dan konseling di sekolah. 
Pribadi unggul yaitu suatu keadaan manusia sebagai perseorangan yang memiliki sifat-sifat yang lebih tinggi/baik daripada orang lain. Dengan seseorang memiliki pribadi unggul ini akan membuat dirinya terlihat lebih baik dari pada orang lain dalam hal pribadinya. Proses pembentukan pribadi unggul ini secara umum dilakukan dengan menanamkan nilai-nilai yang baik kepada diri setiap siswa dalam program sekolah yaitu apel pagi sehingga diharapkan pribadipribadi unggul ini dapat terbentuk.

Secara khusus, pembentukan pribadi unggul dilaksanakan oleh guru BK melalui pemberian layanan-layanan bimbingan dan konseling. Adapun layananlayanan yang digunakan dalam membentuk pribadi unggul siswa yaitu layanan orientasi dan informasi. Akan tetapi pemberian layanan ini dilaksanakan kurang maksimal, dikarenakan pemberian layanan-layanan bimbingan dan konseling yang mengacu pada program bimbingan dan konseling belum sepenuhnya berjalan dengan baik, karena tidak tersedianya jadwal khusus bimbingan dan konseling, sehingga pemberian dilakukan secara insidental. Pemberian layananlayanan bimbingan dan konseling secara insidental dilakukan dengan memanfaatkan jadwal pelajaran yang kosong, sehingga pemberian layananlayanan BK dilaksanakan apa adanya tanpa ada persiapan terlebih dahulu. Berdasarkan penjelasan di atas, implementasi dari kompetensi kepribadian guru BK terbukti telah mampu membentuk pribadi unggul siswa-siswanya, akan tetapi belum maksimal sehingga menyebabkan sebagian siswa saja yang memiliki pribadi unggul ini sedangkan sebagian lainnya masih memiliki tiga, dua atau bahkan salah satu dari bentuk pribadi unggul tersebut.

\section{KESIMPULAN}

Berdasarkan hasil penelitian dan pembahasan tentang kompetensi kepribadian Guru BK dan dampaknya terhadap kepribadian siswa di SMP N 1 Kerinci, maka dapat disimpulkan bahwa hasil persentase pada aspek Beriman dan bertakwa kepada Tuhan Yang Maha Esa dalam kriteria baik dengan persentase $76,4 \%$, aspek Menghargai dan menjunjung tinggi nilai- nilai kemanusiaan dan kebebasan untuk memilih berada pada kriteria baik dengan persentase $71,5 \%$, aspek Menunjukan integritas dan stabilitas kepribadian yang kuat berada pada kriteria baik dengan persentase 73,2\% dan aspek Menampilkan kinerja berkualitas tinggi juga berada pada kriteria baik dengan persentase 72,5\%, jadi tiap-tiap aspek kompetensi kepribadian yang secara keseluruhan termasuk dalam kriteria baik. Kepribadian siswa terlihat melalui beberapa askpek diantaranya; menampilkan akhlak yang mulia berada pada kriteria baik dengan persentase $77 \%$, disiplin mengunakan waktunya berada pada kriteria cukup baik dengan persentase $70 \%$, 
mandiri berada pada kriteria cukup baik dengan persentase $72 \%$ serta percaya diri berada pada kriteria cukup baik dengan persentase $74 \%$.

Secara khusus, aplikasi kompetensi kepribadian guru BK dilaksanakan melalui pemberian layanan-layanan BK. Adapun layanan-layanan yang digunakan dan berdampak terhadap pribadi siswa yaitu layanan orientasi dan informasi. Pemberian layanan lain sesuai program BK belum sepenuhnya berjalan dengan baik, karena tidak tersedianya jadwal khusus BK, sehingga pemberian dilakukan secara insidental dilakukan dengan memanfaatkan jadwal pelajaran yang kosong, sehingga pemberian layanan-layanan BK dilaksanakan apa adanya tanpa ada persiapan terlebih dahulu.

\section{REFERENSI-REFERENSI}

Alimin. (2015). Analisis Kompetensi Kepribadian Guru Pendidikan Agama Islam SMP di Tarakan. Jurnal Kebijakan Dan Pengembangan Pendidikan, 3(1), 61-65.

Badan Nasional Sertifikasi Profesi. (2008). Peraturan Menteri Pendidikan Nomor 27 Tahun 2008 tentang Standar Kualifikasi dan Kompetensi Konselor. BNSP.

Latipun. (2006). Psikologi Konseling. UMM Press.

Prasetiya, B. (2013). Kompetensi Kepribadian Guru PAI Dalam Memotivasi Belajar Siswa. EDUKASI: Jurnal Pendidikan Islam, 1(2), 226-238.

Rahmiyanda, Tanra, A., \& Nurdin, M. (2016). Pengaruh Kompetensi Kepribadian Guru IPA Terhadap Hasil Belajar Siswa SMP Negeri 3 Palu. Jurnal Online Pendidikan Biologi, $4(2)$.

Saudagar, F., \& Idrus, A. (2011). Pengembangan Profesionalitas Guru. Gaung Persada Press.

Surya, M. (2003). Psikologi pembelajaran dan pengajaran. Yayasan Bhakti Winaya.

Susanti, N. I. D., Permata, R. V., \& Muchtarom, M. (2017). Kompetensi Kepribadian Guru PPKn Melalui Keteladanan Dan Implikasinya Terhadap Pembentukan Karakter Disiplin Siswa (Studi Di Smp Negeri 1 Mojolaban Kabupaten Sukoharjo). PKn Progresif, 12(2), 649662.

Wardati, L. (2018). Analisis Implementasi Kompetensi Kepribadian Guru Dalam Motivasi Belajar Di MTs Muhamadiyah-15 di Medan. Hikmah, 15(2), 93-103.

Winkel, W. S., \& Hastuti, S. (2007). Bimbingan dan Konseling di Institusi Pendidikan. Media Abadi.

Yusuf, A. M. (2013). Metodologi penelitian:kuantitatif, kualitatif, dan penelitian gabungan. UNP Press. 